\title{
MENINGKATKAN HASIL BELAJAR SISWA PADA MATA PELAJARAN IPS DENGAN MENGGUNAKAN MODEL PEMBELAJARAN WORD SQUARE DI KELAS IV SDN 101801 KEDAI DURIAN
}

\author{
Risma Sitohang, Amrina Manullang \\ Surel: rismasihotang@gmail.com
}

\begin{abstract}
The study used the Word Square model learning action. The subjects in this study were class IV D SDN 101801 Kedai Durian, amounting to 29 people consisting of 13 women and 16 men. The object of this research is the use of the Word Square learning model. This research was carried out in two cycles, namely cycle I and cycle II cycle, namely cycle I and II where in each cycle of 4 stages, namely: planning, implementation, observation and reflection. Data were analyzed using, it was found from pretest data obtained by students who completed $(10.35 \%)$ and $(89.65 \%)$ which were not completed with a classical average value of 46.20. Keywords: Model, Learning Outcomes
\end{abstract}

\begin{abstract}
ABSTRAK
Penelitian menggunakan dengan tindakan pembelajaran model Word Square. Subjek dalam penelitian ini adalah kelas IV D SDN 101801 Kedai Durian yang berjumlah 29 orang yang terdiri dari 13 perempuan dan 16 laki-laki laki. Objek penelitian ini adalah penggunaan Model pembelajaran Word Square. Penelitian ini dilaksanakan dalam dua siklus, yakni siklus I dan siklus II siklus yaitu siklus I dan II dimana pada tiap siklus dari 4 tahapan yaitu: perencanaan, pelaksanaan, observasi dan refleksi. Data dianalisis menggunakan, ditemukan dari data pretest diperoleh siswa yang tuntas sebanyak $(10,35 \%)$ dan $(89,65 \%)$ yang belum tuntas dengan nilai rata-rata klasikal sebesar 46,20.
\end{abstract}

Kata Kunci : Model, Hasil belajar

\section{PENDAHULUAN}

Pendidikan adalah sebuah wahana dimana terjadinya kegiatan interaksi belajar dan mengajar yang bertujuan untuk membimbing dan memimpin anak didik kedalam proses pertumbuhan dan perkembangan secara optimal, agar dapat berdiri sendiri dan bertanggung

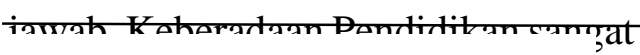
Dosen FIP UNIMED penting dalam pembentukan karakter individu sejak usia dini sehingga anak di masa depan dapat diterima secara baik oleh lingkungannya serta mampu mewujudkan cita-cita pendidikan Risma: Meningkatkan Hasil...

Salah satu upaya untuk meningkatkan mutu pendidikan di Indonesia yakni melalui perbaikan

Accepted: 3 Desember 2018

Published: 18 Desember 2018 
proses pembelajaran di sekolah. Dalam setiap kegiatan pembelajaran di sekolah aktivitas dan hasil belajar merupakan beberapa faktor yang mendapat perhatian penting. Pembelajaran yang baik dapat menumbuhkan gairah siswa dan keaktifan dalam belajar daripada guru. Oleh karena itu guru juga dituntut untuk mampu memilih dan menggunakan model pembelajaran yang sesuai dengan materi yang diajarkan.

IPS merupakan salah satu mata pelajaran yang diberikan di SD yang erat hubungannya dengan interaksi antar sesama manusia dengan lingkungannya. Pembelajaran IPS sebagai bidang studi yang diberikan pada jenjang pendidikan, bukan hanya memberi bekal pengetahuan saja, tetapi juga memberikan bekal nilai dan sikap serta keterampilan dalam kehidupan siswa di masyarakat, bangsa dan negara untuk menjadi warga negara yang berkesadaran tinggi dan bertanggungjawab serta dapat berpartisipasi dalam proses sosial yang ada didalam masyarakat. Mata pelajaran IPS sangat penting bagi siswa, dimana pembelajaran IPS mengajarkan kepada siswa bagaimana cara hidup bergaul, berinteraksi serta berkomunikasi yang baik dengan lingkungannya dan mengajarkan kepada siswa untuk

\begin{tabular}{rrrr} 
p-ISSN 2407-4934 & & \multicolumn{2}{r}{ kesadaran } \\
e-ISSN 2355-1747 & & ah & sosial
\end{tabular}

Secara umum tujuan belajar IPS adalah 1) Membekali siswa dengan pengetahuan sosial yang berguna ketika siswa kembali ke masyarakat. 2) Membekali siswa dengan kemampuan mengidentifikasi, menganalisis dan menyusun alternatif pemecahan sosial yang terjadi dalam kehidupan masyarakat. 3) Membekali siswa dengan kemampuan berkomunikasi dengan masyarakat dari berbagai latar belakang keilmuan dan keahlian. 4) Membekali siswa dengan kesadaran, sikap mental yang positif dan keterampilan terhadap pemanfaatan lingkungan hidup tersebut. 5) Membekali siswa dengan kemampuan mengembangkan pengetahuan dan keilmuan IPS sesuai dengan perkembangan kehi ESJ VOLUME 8, NO. 3,

Secara umum pembelajaran IPS masih mengalami beberapa masalah yaitu: 1) sebagian besar guru IPS belum terampil menggunakan beberapa model mengajar. 2) ketersediaan alat dan bahan belajar belum memadai. 3) karena kurangnya guru dalam menggunakan model pembelajaran, proses belajar mengajar IPS masih dilakukan dalam bentuk pembelajaran konvesional. 4) dalam hal implementasi atau proses pelaksanaan kurikulum ini guru yang mendapat sosialisasi dalam bentuk penataran atau diklat sangat terbatas sekali. 5) sebagian masyarakat Indonesia belum siap mengadaptasi atau mengadopsi budaya dan peradaban asing yang mulai merambah secara global. 
Sedangkan materi-materi IPS yang luas membuat siswa merasa kesulitan dalam memahami materi dan kurang berminatnya siswa dalam pembelajaran IPS. Selain itu, faktor malas membaca juga menambah anggapan bahwa mata pelajaran IPS itu sulit. Faktor guru juga mempengaruhi kelancaran pembelajaran IPS yang dilaksanakan. Penerapan metode ceramah yang dominan didukung dengan ketiadaan media pembelajaran, dan kurangnya dalam penggunaan model pembelajaran akan menambah masalah pembelajaran IPS.

Berdasarkan observasi dan informasi yang diperoleh peneliti ketika melakukan penelitian di SDN 101801 Kedai Durian, bahwa hasil belajar siswa masih rendah. Hal ini ditunjukkan dari nilai yang diperoleh sebagian siswa masih belum mencapai kriteria ketuntasan minimal (KKM) yaitu 70. Dari jumlah keseluruhan siswa kelas IV ${ }^{\mathrm{D}}$ yaitu 29 orang, 29 siswa yang memiliki nilai dibawah nilai KKM dengan persentase $100 \%$. Dan berdasarkan pengalaman PPL, peneliti juga melihat beberapa masalah yang dihadapi dalam pembelajaran IPS yang dilakukan di kelas IV A SD Negeri 101801 Kedai Durian diantaranya adalah 1) rendahnya hasil belajar siswa pada mata pelajaran IPS. 2) kurangnya perhatian siswa dalam mengikuti proses pembelajaran IPS. Hal ini dapat dilihat dari beberapa siswa yang diam dan ada pula siswa yang berbicara saat guru

menjelaskan materi pelajaran IPS, 3) kurangnya kemampuan guru dalam menggunakan strategi, metode, model, dan media pembelajaran yang variatif. Hal ini terlihat dari cara pengajaran guru yang masih berpusat pada guru dan yang masih berfokus hanya menjelaskan apa yang ada pada buku dan menyuruh siswa untuk mencatat dan menghafal apa yang ada dibuku pelajaran 4) suasana belajar yang kurang menyenangkan. Hal ini terlihat dari proses pembelajaran yang pasif tanpa ada timbal balik.

Berdasarkan permasalahanpermasalahan yang ada dalam pembelajaran IPSyang disajikan di atas, salah satu permasalahnnya adalah rendahnya hasil belajar siswa pada mata pelajaran IPS. Untuk mengatasi permasalahan rendahnya hasil belajar siswa salah satu solusinya adalah peran guru dalam penggunaan model pembelajaran. Dengan menggunakan model pembelajaran dapat meningkatkan hasil belajar siswa. Dari beberapa model pembelajaran yang ada salah satu model pembelajaran yang dapat digunakan adalah model Risma: Meningkatkan Hasil...

Model pembelajaran Word
Square
pembelajaran yang mengunakan
kotak-kotak berupa teka-teki silang
sebagai alat di p-ISSN 2407-4934
materi ajar di e-ISSN 2355-1747
mengajar. Jad., …...............
adalah adalah media utama dalam
menyampaikan materi ajar. Model
pembelajaran Word Square ini baik


digunakan dalam rangka meningkatkan daya pikir siswa secara acak dan mempermudah siswa dalam memahami materi ajar. Di samping itu dengan menggunakan model ini akan meningkatkan aktivitas belajar siswa, sehingga siswa tidak merasa jenuh saat proses pembelajaran.

Penyajian materi IPS pada
umumnya selalu bersifat
konvensional dan klasikal. Sehingga siswa cepat bosan, jenuh dan merasa tidak termotivasi untuk mengikuti setiap alur pembelajaran IPS, terkhusus pada materi Kegiatan Ekonomi Masyarakat yang Berkaitan Dengan Sumber Daya Alam, materi ini terlalu membosankan apabila hanya dikuasai oleh satu orang siswa saja dalam kelompoknya sehinnga akan lebih baik jika setiap siswa bekerja sama atau masing-masing siswa berpartisipasi dalam setiap kerja kelompok yang dilakukan. Selain itu, para siswa sering mengabaikan pekerjaan siswa untuk mengerjakan soal-soal sehingga hasil belajar siswa rendah dan banyak siswa yang mengobrol ketika siswa merasa bosan dengan metode ceramah yang dilakukan guru dalam proses pembelajaran. Berdasarkan kenyataan itu perlu dilakukan peningkatan hasil belajar siswa dalam helaiar IPS

\section{p-ISSN 2407-4934}

e-ISSN 2355-1747 dalam pembelajaran IPS adalah model pembelajaran Word Square. Model pembelajaran Word Square salah satu model pembelajaran yang mudah diterapkan, melibatkan aktivitas seluruh siswa, dan dapat diterapkan untuk semua mata pelajaran. Model ini dapat menghindarkan rasa bosan siswa dalam belajar karena model ini tidak hanya melibatkan peran aktif guru tetapi juga melibatkan peran aktif siswa dalam pembelajaran. Model pembelajaran ini dapat membantu siswa untuk mengembangkan dan penguasaan keterampilan dalam proses kognitif siswa. Dengan demikian penggunaan model Word Square diharapkan mampu meningkatkan hasil belajar siswa pada pokok bahasan Kegiatan Ekonomi Masyarakat Yang Berkaitan Dengan Sumber Daya Alam.

\section{Implementasi}

model pembelajaranini adalah guru menyampaikan materi sesuai kompetensi yang ingin dicapai peserta didik, sebelum mengerjakan lembar kerja siswa guru terlebih dahulu menerangkan bagaimana cara penggunaan model pembelajaran Word Square, di lembar kerja siswa yang dibagikan dalam kelompok siswa akan mencari kata-kata pada kotak yang berkaitan dengan materi nemhelaiaran dimana kata vano purnurajaran yany unun digun....... ditemukan siswa merupakan jawaban dari pertanyaan yang akan dibuat siswa,kemudian mengarsir huruf dalam kotak sesuai jawaban di
ESJ VOLUME 8, NO. 3, DESEMBER 2018

lembar kegiatan yang telah dibagikan guru, kemudian siswa membuat pertanyaan sesuai kata yang ditemukan dalam kotak, selanjutnya 
guru memberikan poin setiap jawaban dalam kotak.

\section{METODE PENELITIAN}

Penelitian ini direncanakan di Kelas IV A SDN 101801 Kedai Durian dan penelitian ini dilrencanakan selama 2 bulan pada semester II (dua) yang dimulai dari bulan Februari sampai Maret.

Subjek dalam penelitian ini adalah siswa kelas IV ${ }^{\mathrm{D}}$ SDN 101801 Kedai Durian tahun ajaran 2017/2018 sebanyak 1 kelas yang terdiri dari 29

\section{HASIL DAN PEMBAHASAN}

Penelitian ini menggunakan Penelitian Tindakan Kelas. Penelitian ini dilaksanakan di SDN 101801 Kedai Durian yang beralamat di Jalan kasih Dusun Kedai Durian Kecamatan Deli Tua Kabupaten Deli Serdang yang dipimpin oleh ibu Suharni, S.Pd. Jumlah tenaga pengajar sebanyak 29 orang.. Penelitian ini dilakukan di kelas $\mathrm{IV}^{\mathrm{D}}$ dengan jumlah siswa sebanyak 29 orang yang terdiri dari 13 perempuan dan 16 laki-laki. Berdasarkan hasil penelitian dan refleksi yang dilakukan, peneliti memperoleh hasil belajar siswa masih sangat rendah. Hal ini dapat dilihat pada hasil pretest siswa. Menurut Purwanto (2011:38) "belajar merupakan proses dalam individu yang berinteraksi dengan lingkungan untuk endapatkan perubahan dalam perilakunya". Oleh siswa. Sedangkan yang menjadi objek penelitian adalah model pembelajaran Word Square dalam meningkatkan hasil belajar siswa pada mata pelajaran IPS materi pokok kegiatan ekonomi masyarakat yang berkaitan dengan sumber daya alam.Penelitian ini memilik beberapa tahap pelaksanaan dilakukan di dalam kelas. Dan menurut Arikunto (2014:16) terdapat empat tahapan yang dilakukan dalam melakukan penelitian yaitu:1 perencanaan, 2) pelaksanaan, 3) pengamatan, 4) refleksi.

Risma: Meningkatkan Hasil...

belajaran dan melibatkan siswa dalam proses pembelajaran. Dengan demikian dapat dilihat bahwa pada pretest dengan jumlah siswa yang tuntas belajar sebanyak 3 siswa dengan persentase $10,35 \%$ dan siswa yang belum tuntas sebanyak 24 siswa dengan persentase $89,65 \%$ dengan nilai rata-rata pretest 46,20 . Dar hasil pretest tersebut dapat diketahui bahwa hasil siswa masih tergolong rendah. Ini dikarenakan siswa kurang memahami materi pelajaran sehingga siswa kesulitan dalam menjawab soal pilihan ganda materi pokok kegiatan ekonomi masyarakat yang berkaitan dengan sumber daya alam. Sehingga peneliti melakukan upaya untuk meningkatkan hasil belajar siswa dengan menggunakan model pembelajaran $W_{o}$ 
Menurut Istarani (2012: 181) "Model pembelajaran Word Square merupakan model pembelajaran yang mengunakan kotak-kotak berupa teka-teki silang sebagai alat dalam menyampaikan materi ajar dalam proses belajar mengajar.

\section{Selanjutnya,}

setelah

dilakukan dengan menggunakan model pembelajaran Word Square pada siklus I, peneliti kemudian memberikan post test siklus I untuk mengetahui tingkat pemahaman siswa terhadap materi yang disampaikan oleh peneliti. Pada siklus I terdapat jumlah siswa yang tuntas sebanyak 17 orang dengan persentase $58,62 \%$ dan siswa yang belum tuntas sebanyak 12 orang dengan persentase $41,38 \%$ dengan nilai- rata 64,48 dengan kategori cukup. Hal ini menunjukkan bahwa pada siklus I masih tergolong rendah karena tidak mencapai nilai rata-rata klasikal $70 \%$. Sehingga peneliti harus lebih berupaya untuk memperbaiki kendala-kendala yang terjadi di post test I pada siklus selanjutnya.

Setelah peneliti melakukan upaya perbaikan untuk lebih meningkatkan hasil belajar sisw dengan menggunakan model Word Square pada tindakan siklus II. Setelh dilakukannya tindakan pada siklus II, peneliti selanjutnya memberikan post test II kepada siswa untuk mengetahui sejauhmana pemahaman siswa

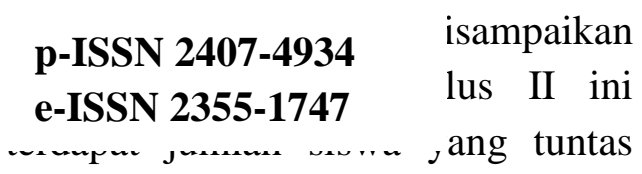

sebanyak 25 orang dengan persentase $86,20 \%$ dan siswa yang belum tuntas sebanyak 4 siswa dengan persentase $13,80 \%$ dengan nilai rata-rata 80,34 dengan kategori baik. Ini menunjukkan bahwa pada siklus II telah mencapai nilai rata-rata klsikal yaitu $70 \%$.

Untuk melihat lebih jelas peningkatan hasil belajar siswa pada pretest, post test I, dan post test II dapat dilihat pada tabel berikut. Model pembelajaran ini dapat membantu siswa untuk mengembangkan dan penguasaan keterampilan dalam proses kognitif siswa. Salah satu upaya untuk meningkatkan mutu pendidikan di Indonesia yakni melalui perbaikan proses pembelajaran di sekolah.

Dalam setiap kegiatan pembelajaran di sekolah aktivitas dan hasil belajar merupakan beberapa faktor yang mendapat perhatian penting. Pembelajaran yang baik dapat menumbuhkan gairah siswa dan keaktifan dalam belajar daripada guru. Oleh karena itu guru juga dituntut untuk mampu memilih dan menggunakan model pembelajaran yang sesuai dengan materi yang diajarkan. 
Tabel 4.11 Distribusi Hasil Belajar Pada Pretest, Siklus I,

DanSiklus II

\begin{tabular}{|c|c|c|c|c|c|c|}
\hline \multirow[t]{2}{*}{ No } & \multirow[t]{2}{*}{$\begin{array}{c}\text { Jenis } \\
\text { Tes }\end{array}$} & \multirow{2}{*}{$\begin{array}{c}\text { Nilai } \\
\text { rata- } \\
\text { rata }\end{array}$} & \multicolumn{2}{|c|}{ Jumlah Siswa } & \multicolumn{2}{|c|}{$\begin{array}{l}\text { Persentase } \\
\text { Ketuntasan }\end{array}$} \\
\hline & & & Tuntas & $\begin{array}{l}\text { Belum } \\
\text { Tuntas }\end{array}$ & Tuntas & $\begin{array}{l}\text { Belum } \\
\text { Tuntas }\end{array}$ \\
\hline 1 & Pretest & 46,20 & $\begin{array}{c}3 \\
\text { oran } \\
\mathrm{g}\end{array}$ & $\begin{array}{c}26 \\
\text { Orang }\end{array}$ & $10,35 \%$ & $89,65 \%$ \\
\hline 2 & $\begin{array}{c}\text { Post } \\
\text { test } \\
\text { Siklus } \\
\text { I } \\
\end{array}$ & 64,48 & $\begin{array}{c}17 \\
\text { oran } \\
\mathrm{g}\end{array}$ & $\begin{array}{c}12 \\
\text { orang }\end{array}$ & $58,62 \%$ & $41,38 \%$ \\
\hline 3 & $\begin{array}{c}\text { Post } \\
\text { Test } \\
\text { Siklus } \\
\text { II }\end{array}$ & 80,34 & $\begin{array}{c}25 \\
\text { oran } \\
g\end{array}$ & $\begin{array}{c}4 \\
\text { orang }\end{array}$ & $86,20 \%$ & 13,80 \\
\hline
\end{tabular}

Berdasarkan diagram di atas dapat dilihat bahwa pada pretest, post test I, post test II mengalami peningkatan pada setiap siklus nya. Dimana siswa yang tuntas pada pretest dengan persentase $10,35 \%$, siswa yang tuntas pada post test siklus I dengn persentase $58,68 \%$ dan siswa yang tuntas pada post test siklus II dengan persentase $86,20 \%$.

Hal ini terlihat setelah dilakukanya perbaikan dari siklus I ke siklus II dalam proses belajar mengajar dengan menggunakan model pembelajaran Word Square pada pelajaran IPS tampak lebih aktif dan hasil belajar IPS siswa Risma: Meningkatkan Hasil...

Hasil penelitian terdahulu yang mendukung penelitian ini yaitu berdasarkan penelitian yang dilakukan oleh Masta Ginting (2015) dengan judul "Meningkatkan Hasil Belajar IPS Menggunakan Model Pembelajaran Word Square Pada SDN 064975 Medan Denai“. Permasalahan dalam penelitian ini adalah rendahnya hasil belajar siswa pada mata pelajaran IPS. Analisis data yang digunakan di awal pembelajaran terdapat 48,86 dan masih tergolong rendah. Pada siklus I rata-rata ni] p-ISSN 2407-4934 e-ISSN 2355-1747 
II meningkat dengan nilai rata-rata 82,95 .

Dalam jurnal Suratman (2014) dalam jurnal "Penggunaan Model Word Square Dalam Peningkatan Hasil Belajar IPS Siswa Kelas IV SDN 2 Sidogede”. Teknik pengumpulan datanya observasi, wawancara dan tes. Validitas data menggunakan teknik triangulasi. Hasil penelitian menunjukkan penggunaan model Word Square dapat meningkatkan hasil belajar kelas IV SD.

Dan dalam jurnal Naeklan Simbolon (2014) dengan judul "Meningkatkan Motivasi Belajar Siswa Dengan Menggunakan Model Pembelajarn Word Square Kelas IV SD Negeri 101868 Desa Sena Batang Kuis". Permasalahan dalam penelitian ini adalah rendahnya motivasi belajar IPS siswa pada mata pelajaran IPS. Berdasarkan analisis data hasil penelitian menunjukkan pada siklus I $22,58 \%$ memiliki kategori termotivasi, 41,94\% cukup termotivasi dan $35,48 \%$ belum termotivasi. Pada siklus II mengalami

$$
\begin{array}{lll}
\text { p-ISSN 2407-4934 } & \text { gori sangat } \\
\text { e-ISSN 2355-1747 } & j \quad \text { kategori }
\end{array}
$$

termotivasi.
Dengan demikian penggunaan model pembelajaran Word Square dapat meningkatkan hasil belajar siswa pada pelajaran IPS materi pokok kegiatan ekonomi masyarakat yang berkaitan dengan sumber daya alam kelas IV SDN 101801 Kedai durian T.A 2017/2018.

\section{SIMPULAN}

Berdasarkan hasil penelitian dan pembahasan, maka diperoleh kesimpulan bahwa dengan menggunakan model pembelajaran Word Square dapat meningkatkan hasil belajar siswa mata pelajaran IPS Selanjutnya, dilakukan dengan menggunakan model pembelajaran Word Square pada siklus I, peneliti kemudian memberikan post test siklus I untuk mengetahui tingkat pemahaman siswa terhadap materi yang disampaikan oleh peneliti. materi pokok kegiatan ekonomi masyarakat yang berkaitan dengan sumber daya alam di kelas IV SDN 101801 Kedai Durian T.A 2016/2017 Hal ini dapat dilihat dari:

ESJ VOLUME 8,

1. Pembelajaran IPS $\begin{array}{r}\text { dengan } \\ \text { model }\end{array}$
menggunakan
pembelajaran Word Square dapat
membuat siswa lebih aktif dalam


belajar dan menjadikan pembelajaran lebih menyenangkan sehingga lebih meningkatkan pemahaman mereka terhadap materi kegiatan ekonomi masyarakat yang berkaitan dengan sumber daya alam karena dalam pelaksanaan model pembelajaran Word Square siswa diarahkan untuk mencari kata yang berkaitan dengan materi yang dipelajari pada Word Square (kotak kata) yang telah disediakan dan dari kata yang ditemukan siswa membuat pertanyaan $\mathrm{d}$

2. Pada pretest diperoleh ketuntasan belajar siswa sebanyak 3 siswa $(10,35 \%)$ yang tuntas belajar dan 26 siswa $(89,65 \%)$ yang belum tuntas dengan nilai rata-rata klasikal sebesar 46,20.

3. Pada siklus I diperoleh ketuntasan belajar siswa sebanyak 17 siswa $(58,62 \%)$ yang tuntas belajar dan 12 siswa $(41,38 \%)$ yang belum tuntas dengan nilai rata-rata klasikal sebesar 64,48.

4. Pada siklus II diperoleh ketuntasan belajar siswa sebanyak 25 siswa $(86,20 \%)$ yang tuntas belajar dan 4 siswa $(13,80 \%)$ yang belum tuntas dengan nilai ratarata klasikal sebesar 80,34.

Dari hasil pengamatan kemampuan guru dalam proses pembelajaran mengalami peningkatan pada setiap pertemuannya. Pada siklus I diperoleh nilai rata-rata 73,52. Selanjutnya pada siklus II diperoleh nilai rata-rata 86,76 .

Saran

Adapun saran yang dapat penulis berikan berdasarkan hasil penelitian yang telah dilakukan a Risma: Meningkatkan Hasil...

1. Diharapkan kepada guru-guru agar menggunakan model pembelajaran Word Square sebagai solusi untuk memperbaiki proses pembelajaran karena melalui pembelajaran Word Square ini dapat meningkatkan hasil belajar siswa khusunya pada mata pelajaran IPS materi pokok kegiatan ekonomi masyarakat yang berkaitan dengan sumber dava alam.

2. Kepadi $\begin{aligned} & \text { p-ISSN 2407-4934 } \\ & \text { e-ISSN 2355-1747 }\end{aligned}$
101801 neual uurlall, ayal' 
mengkoordinasikikan

pelaksanaan pembelajaran dengan menggunakan model pembelajaran Word Square.

\section{DAFTAR RUJUKAN}

Amri, Sofan. 2013. Pengembangan \& Model Pembelajaran dalam Kurikulum 2013. Jakarta: Prestasi Pustaka.

Arikunto ,Suharsimin. 2014. Prosedur Penelitian. Jakarta: Rineka Cipta

Daryanto.2017. Pembelajaran Abad 21. Yogyakarta: Gava Media

Dewi, Rosmala. 2010. Penelitian Tindakan Kelas. Medan: Pasca Sarjana Unimed

Dimyati dan Mudjiono. 2013. Belajar Dan Pembelajaran. Jakarta: PT Rineka Cipta.

Gunawan, Rudi. 2011. Pendidikan IPS Filosofi, Konsep dan Aplikasi. Bandung : Alfabeta.

Ginting, Masta. 2015. "Meningkatkan Hasil Belajar Siswa Dengan Menggunakan Model Pembelajarn Word $\begin{array}{llr}\text { p-ISSN 2407-4934 } & \text { a Mata } \\ \text { e-ISSN 2355-1747 } & \text { it Kelas IV }\end{array}$ uעי vute,j Medan Denai”, dalam jurnal Handayani PGSD FIP
UNIMED, Vol 4,( 1), hlm. 87-93.

Hamalik, Oemar. 2013. Kurikulum Dan Pembelajaran. Jakarta: Bumi Aksara.

Istarani.2012.58 Model Pembelajaran Inovatif.Medan:Media Persada.

Kurniasih, Imas, dan Berlin Sani. 2016. Ragam Pengembangan Model Pembelajaran. Yogjakarta: Kata Pena

Muslich. 2009. KTSP Pembelajaran Berbasis Kompetensi Dan Konsektual. Jakarta: Bumi Aksara

Purwanto. 2011. Evaluasi Hasil Belajar. Yogjakarta: Pustaka Belajar.

Rusman. 2012. Model-Model Pembelajaran

Mengembangkan

Profesionalisme Guru. Jakarta: Rajawali Pers.

Sani, Ridwan Abdullah. 2014. Inovasi Pembelajaran. Jakarta: Bumi Aksara.

Sanjaya, Wina. 2010. Kurikulum dan Pembelajaran. Jakarta: Kencana Prenada M M din Group.

ESJ VOLUME 8, NC

Sapriya. 2007. Konsep Dasar IPS.

Bandung. UPI Press

Sardjiyo, dkk. 2007. Pendidikan IPS di $S D$. Jakarta: Universitas Terbuka. 
Sudjana, Nana. 2016. Penilaian Hasil Proses Belajar Mengajar. Bandung: PT Remaja Rosdakarya.

Suratman. 2014."Penggunaan Model Word Square Dalam Meningkatkan Hasil Belajar Siswa Kelas IV SDN 2 Sidogede", dalam FKIP PGSD Universitas Sebelas Maret, vol 4 (11), hlm.1-7.

Shoimin, Aris. 2016. 68 Model Pembelajaran Inovatif dalam Kurikulum 2013. Yogyakarta: Ar-Ruzz Media

Simbolon,

Naeklan.2015.'Meningkat kan Hasil Belajar Siswa Dengan Penerapan Model Logan Avenue Problem Solving Di Sekolah Dasar", dalam Proceeding seminar Nasional Inovasi dan Teknologi Informasi, Vol 1 (1), hlm.143-147.

Simbolon, naeklan. 2014."Meningkatkan
Motivasi Belajar Siswa

Dengan Menggunakan

Menggunakan

Pembelajaran Word

Square Kelas IV SD Negeri 101868 Desa Sena Batang Kuis", dalam jurnal School Education 2, Vol 2 (01), hlm. 87-93.

Slameto. 2013.Belajar dan Faktor-

Faktor yang mempengaruhinya.Jakarta: Rineka Cipta

Supriatna, dkk. 2009. Pendidikan IPS di SD. Bandung: UPI press.

Suprijono, Agus. 2012. Cooperative Learning. Yogyakarta: Pustaka Belajar

Syah, Muhibbin. 2009.Psikologi Belajar. Jakarta: Rajawali Pers

Trianto. 2011. Mendesain Model Pembelajaran Inovatif dan Progresif. Jakarta: Kencana

Yamin, Moh. 2015. Teori Dan Metode Pembelajaran. Malang: Cita Intarns Selaras

p-ISSN 2407-4934

e-ISSN 2355-1747 